\title{
EFFECT OF MONETARY POLICY ON ECONOMIC GROWTH IN NIGERIA: AN EMPIRICAL INVESTIGATION
}

\author{
Lawrence Olisaemeka UFOEZE ${ }^{1}$, S. O. ODIMGBE ${ }^{2}$, V. N. EZEABALISI ${ }^{3}$, \\ Udoka Bernard ALAJEKWU ${ }^{4}$ \\ ${ }^{1,3}$ Department of Banking and Finance, Chukwuemeka Odumegwu Ojukwu \\ University, Anambra State, Nigeria \\ ${ }^{2}$ Department of Banking and Finance, Madonna University, Okija Campus, \\ Anambra State, Nigeria \\ ${ }^{4}$ Department of Banking and Finance, Nnamdi Azikiwe University, Awka, \\ Anambra State, Nigeria
}

\begin{abstract}
The study investigated the effect of monetary policy on economic growth in Nigeria. The natural log of the GDP was used as the dependent variables against the explanatory monetary policy variables: monetary policy rate, money supply, exchange rate, lending rate and investment. The time series data is the market-controlled period covering 1986 to 2016. The study adopted an Ordinary Least Squared technique and also conducted the unit root and co-integration tests. The study showed that long run relationship exists among the variables. In addition, the core finding of this study showed that monetary policy rate, interest rate, and investment have insignificant positive effect on economic growth in Nigeria. Money supply however has significant positive effect on growth in Nigeria. Exchange rate has significant negative effect on GDP in Nigeria. Money supply and investment granger cause economic growth, while economic growth causes interest rate in Nigeria. On the overall, monetary policy explains $98 \%$ of the changes in economic growth in Nigeria. Thus, the study concluded that monetary policy can be effectively used to control Nigerian economy and thus a veritable tool for price stability and improve output.
\end{abstract}

Keywords: monetary policy; monetary policy rate; money supply; exchange rate; lending rate; investment; Nigeria.

JEL Classification: $\mathrm{E}_{5}$

\section{Introduction}

Monetary policy is a deliberate action of the monetary authorities to influence the quantity, cost and availability of money credit in order to achieve desired 


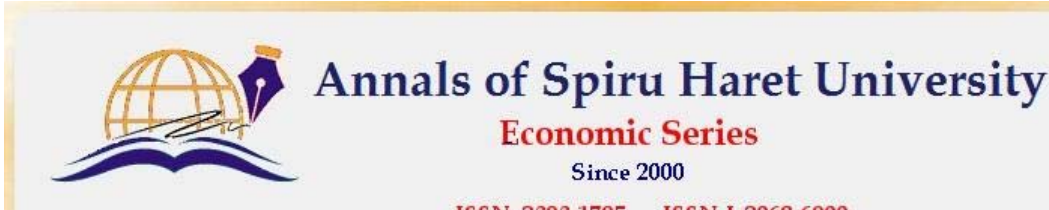

ISSN: 2393-1795 ISSN-L:2068-6900

\section{Issue 1/2018}

macroeconomic objectives of internal and external balances [CBN, 2011]. The action is carried out through changing money supply and/or interest rates with the aim of managing the quantity of money in the economy. Thus, monetary policy as a technique of economic management to bring about sustainable economic growth and development has been the pursuit of nations and formal articulation of how money affects economic aggregates dates back the time of Adams Smith and later championed by the monetary economists. Since the expositions of the role of monetary policy in influencing macroeconomic objectives like economic growth, price stability, equilibrium in balance of payments and host of other objectives, monetary authorities are saddled the responsibility of using monetary policy to grow their economies.

Economic growth could be defined as the increase in the amount of goods and services in a given country at a particular time. This of course indicates that when the real per capita income of a country increases over time, economic growth is taking place. A growing economy produces goods and services in each successive time period, showing that the economy's productive capacity is at increase. Broadly, economic growth implies raising the standard of living of the people and reducing inequalities of income distribution [Jhingan, 2004].

In Nigeria, monetary policy has been used since the Central bank of Nigeria was saddled the responsibility of formulating and implementing monetary policy by Central bank Act of 1958. This role has facilitated the emergence of active money market where treasury bills, a financial instrument used for open market operations and raising debt for government, have grown in volume and value becoming a prominent earning asset for investors and source of balancing liquidity in the market.

Two major periods have characterized monetary policy in Nigeria: the post-and pre-1986 periods. Before 1986, direct monetary control was used in achieving price stability in Nigeria, while the emphasis shifted to market mechanisms after the 1986 market liberalization [Uchendu, 2009]. Prior to 1986, direct monetary instruments such as selective credit controls, administered interest and exchange rates, credit ceilings, cash reserve requirements and special deposits to combat inflation and maintain price stability were employed. The fixing of interest rates at relatively low levels was done mainly to promote investment and growth. Occasionally, special deposits were imposed to reduce the amount of excess reserves and credit creating capacity of the banks [Uchendu, 2009; Okafor, 2009].

In the above period, the monetary control framework seems to have failed to achieve the set monetary targets as their implementation became less effective with time. The rigidly controlled interest rate regime and the non-harmonization of fiscal and monetary policies may have contributed immensely to the adverse effect of 


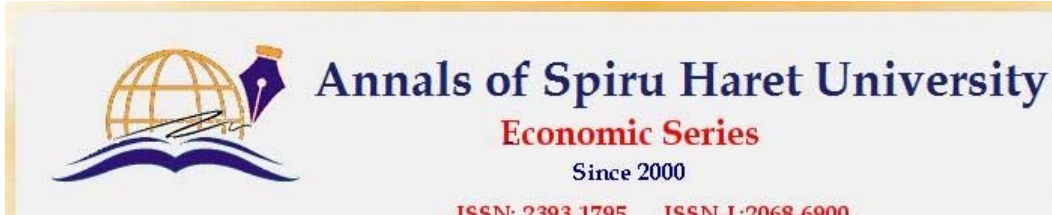

ISSN: 2393-1795 ISSN-I -2068-6900

Issue 1/2018

constraining growth of the money and capital markets. In the Structural Adjustment Programme (SAP) era instead of relying on direct control mechanism for monetary policy, a shift to market-oriented reform was introduced for effective mobilization of savings and efficient resource allocation. Open market operation was the main instrument of the market-based framework.

In Nigeria, monetary policy has been based on a medium-term perspective framework in recent times. The shift was to free monetary policy implementation from the problem of time inconsistency and minimize over-reaction due to temporary shocks. Policies have ranged from targeting monetary aggregates to monitoring and manipulating policy rates to steer the interbank rates and by extension other market rates in the desired direction [Okoro, 2005; Uchendu, 2009]. The extent these strategies have helped to stabilize the economic and engender growth is of immense concern to policy makers and academics.

There have been various regimes of monetary policy in Nigeria. Sometimes, monetary policy is tight and at other times is loose, mostly used to stabilize prices. The economy has also witnessed times of expansion and contraction, but evidently, the reported growth has not been a sustainable one as there is evidence of growing poverty among the populace. The question is, could the period of growth be attributed to appropriate monetary policy? And could the periods of economic down turn be blamed on factors other than monetary policy ineffectiveness? What measures are to be considered if monetary policy would be effective in bringing about sustainable economic growth and development? These are the questions that remain unresolved in Nigeria, which this study would attempt to answer.

Existing empirical studies in Nigeria have not fully answered these questions. Moreover, the present study is unique, because, among the reviewed literature, none included investment in the study of monetary policy, when it is known that monetary policy equally targets to boost investment as it manipulates money supply. Furthermore, only Chuku (2009) has attempted to include the price-based nominal anchors of monetary policy as against the quantity-based nominal anchor used by most researchers in Nigeria. However, this study is an improvement on Chuku (2009), because it does not only include the MPR (used as MPR), but also incorporated other price-based issues such as lending rate in one model. More specifically, among the studies in Nigeria, this is the study that considers only the market-based monetary-based in the investigation of the effect of monetary policy on economic growth. Thus, this study clearly explained the effect of monetary policy on growth from the point of view of liberalised economy. 


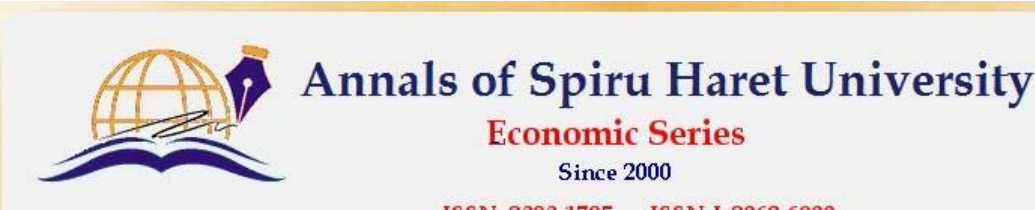

ISSN: 2393-1795 ISSN-L:2068-6900

Issue 1/2018

The main objective of the study is to investigate the effect of monetary policy on economic growth in Nigeria. The specific objectives include examining the effects of monetary policy rate, money supply, exchange rate, interest rate and investment on GDP in Nigeria.

\section{Review of related literature}

2.1. Conceptual review

2.1.1. Concept of monetary policy

Monetary policy is the deliberate use of monetary instruments (direct and indirect) at the disposal of monetary authorities such as central bank in order to achieve macroeconomic stability. Monetary policy is essentially the tool for executing the mandate of monetary and price stability. Monetary policy is essentially a programme of action undertaken by the monetary authorities, generally the central bank, to control and regulate the supply of money with the public and the flow of credit with a view to achieving predetermined macroeconomic goals [Dwivedi, 2005].

Monetary policy is one of the tools of controlling money supply in an economy of a nation by the monetary authorities in order to achieve a desirable economic growth. Governments try to control the money supply because most governments believe that its rate of growth has an effect on the rate of inflation. Hence, monetary policy comprises those government actions designed to influence the behaviour of the monetary sector. Monetary policies are effective only when economies are characterized by well-developed money and financial markets like developed economies of the world. This is where a deliberate change in monetary variables influences the movement of many other variables in the monetary sector.

Monetary policy has thus been known to be a vital instrument that a country can deploy for the maintenance of domestic price and exchange rate stability as a critical condition for the achievement of a sustainable economic growth and external viability [Adegbite \& Alabi, 2013]. Monetary policy may be inflationary or deflationary depending upon the economic condition of the country. Contractionary policy is enforced to squeeze down the money supply to curb inflation and expansionary policy is to stimulate economic activity to combat unemployment in recession [Shane Hall, 2010].

Monetary policy consists of a Government's formal efforts to manage the money in its economy in order to realize specific economic goals. Three basic kinds of monetary policy decisions can be made about (1) the amount of money in circulation; (2) the level of interest rate; and (3) the functions of credit markets and the banking system [Ogunjimi, 1997]. 


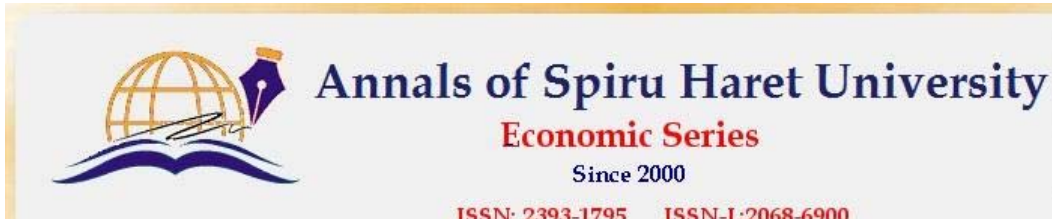

ISSN: 2393-1795 ISSN-I-2068-6900

Issue 1/2018

The combination of these measures is designed to regulate the value, supply and cost of money in an economy, in line with the level of economic activity. Excess supply of money will result in an excess demand for goods and services; prices will rise and balance of payments will deteriorate. The challenge of monetary policy management rest wholly on monetary authorities, which have over the years been committed to its effective control. The performance of monetary policy has improved greatly in recent times - inflation has remained at moderate levels accompanied by high growth of domestic output. To sustain the efforts, there is need for appropriate collaboration with the fiscal authorities, as well as the development of confidence in inter-bank market and the necessary financial market infrastructure is still relevant.

\subsubsection{Concept of economic growth}

Economic growth is a sustained rise in the output of goods, services and employment opportunities with the sole aim of improving the economic and financial welfare of the citizens [Ogbulu \& Torbira, 2012]. Hardwick, Khan and Langmead (1994) have defined economic growth as an increase in a country's productive capacity, identifiable by a sustained rise in real national income.

The economic growth is an important issue in economics and is considered as one of the necessary conditions to achieve better outcomes on social welfare, which is the main objective of economic policy. It is thus an essential ingredient for sustainable development. Economic growth in a country is proxied by Gross Domestic Product (GDP). Thus, in this study, it is conceptualized as the monetary value of all goods and services produced in an economy over a specified period, usually one year.

\subsection{Theoretical foundation}

The theoretical framework on which this study is based is the Keynesian ISLM framework with a Philips curve superimposed on it to determine inflation. The mechanism is such that changes in monetary policy (usually specified as exogenous shifts in monetary aggregates) affect the money supply, which changes interest rate to balance the demand with supply [Chuku, 2009]. The changes in interest rates then affect investment and consumption, which latter cause's changes in output and eventually prices.

Modifying the classical quantity theory of money, the Keynesians believe that money supply, through its transmission mechanism, has indirect effect on the real GDP. Monetarists while agreeing to Keynes that in the short run economy does not operate at full employment, therefore expansionary monetary policy may work 


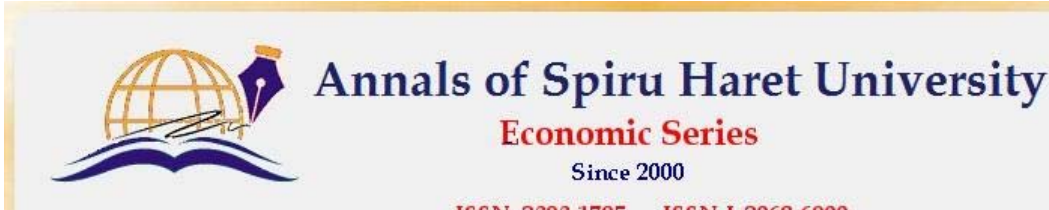

ISSN: 2393-1795 ISSN-L:2068-6900

\section{Issue 1/2018}

positively in the long-run, they support classists that rising money supply will increase inflation only. Therefore, they suggest that the policy must accommodate increase in real GDP without changing price level [LanLord, 2008].

Most of the modern economists are of the view that long-run growth depends upon enhancement of productivity. If an appropriate monetary policy is supplemented by the external environment of suitable liquidity, interest rate, robust demand, soft assistance from the world bank of the financial institutions and debt rescheduling would lead to sustainable economic growth in the long-run [Russell, 2010].

Monetarists strongly believe that monetary policy exact greater impact on economic activity as unanticipated change in the stock of money affects output and growth, i.e. the stock of money must increase unexpectedly for central bank to promote economic growth. In fact, they are of opinion that an increase in government spending would crowd out private sector and such can outweigh any short-term benefits of an expansionary fiscal policy [Adefeso \& Mobolaji, 2010].

On the other hand, the concept of liquidity trap, which is a situation in which real interest rates cannot be reduced by any action of the monetary authorities, was introduced by Keynesian economics. Hence, at liquidity trap an increase in the money supply would not stimulate economic growth because of the downward pressure of investment owing to insensitivity of interest rate to money supply. John Maynard Keynes recommends fiscal policy by stimulating aggregate demand in order to curtail unemployment and reducing it in order to control inflation. While there are several studies on this debates between Keynesian and Monetarist in the developed countries, only fragmented evidence have been provided on this issues in the case of Nigeria [Adefeso \& Mobolaji, 2010[. A case for the use of monetary policy will be further pursued with the view to understanding the effectiveness of monetary policy in enhancing economic growth in Nigeria.

\subsection{Empirical evidences}

Adegbite and Alabi (2013) examined the impact of monetary policy on economic growth in Nigeria, using secondary data from central bank of Nigeria statistical bulletin covering the period of 1970 to 2010. Multiple regressions were employed to analyze data on such variable money supplies; inflation, exchange rate, interest rate and gross domestic product were all found to have significant effects on the Economics Growth with the Adjusted R2 of 58\%. Following the outcome of this study, it is, therefore, concluded that exchange rate stability has played a key role in keeping inflation low for most of the transition period, and that the range of monetary policy instruments available to the authorities has widened in recent years 

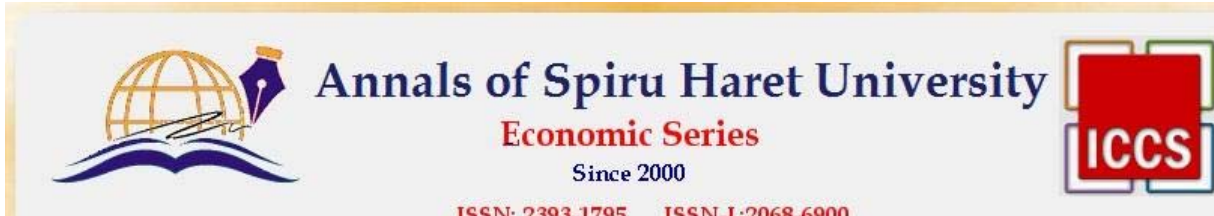

ISSN: $2393-1795 \quad$ ISSN-L-2068-6900

Issue 1/2018

and this has been associated with more stable and predictable changes in money supply and the price level.

Chuku (2009) carried out a controlled experiment using a Structural Vector Autoregression (SVAR) model to trace the effects of monetary policy shocks on output and prices in Nigeria. The study assumed that the Central Bank cannot observe unexpected changes in output and prices within the same period. This places a recursive restriction on the disturbances of the SVAR. Three alternative policy instruments i.e. broad money (M2), minimum rediscount rate (MRR) and the real effective exchange rate (REER) were used. Overall, the study found evidence that monetary policy innovations carried out on the quantity-based nominal anchor (M2) has modest effects on output and prices with a very fast speed of adjustment. While, innovations on the price-based nominal anchors (MRR and REER) have neutral and fleeting effects on output. The study concluded that the manipulation of the quantity of money (M2) in the economy is the most influential instrument for monetary policy implementation.

Gul, Mughal, Rahim (2012) reviewed how the decisions of monetary authorities influence the macro variables such as GDP, money supply, interest rates, exchange rates and inflation. The method of least squares is used in the data. The sample was taken from 1995-2010 and included observations are 187. Result shows that interest rate has negative and significant impact on output. Tight monetary policy in term of increase interest rate has significant negative impact on output. Money supply has strongly positive impact on output that is positive inflation and output is negatively correlated, exchange rate also have negative impact on output which is show from the values.

Amassoma, Nwosa and Olaiya (2011) have appraised monetary policy development in Nigeria and also have examined the effect of monetary policy on macroeconomic variables in Nigeria for the period 1986 to 2009. The study adopted a simplified Ordinary Least Squared technique and also conducted the unit root and co-integration tests. The findings of the study showed that monetary policy have witnessed the implementation of various policy initiatives and has therefore experienced sustained improvement over the years. The result also shows that monetary policy had a significant effect on exchange rate and money supply while monetary policy was observed to have an insignificant influence on price instability. The implication of this finding is that monetary policy has had a significant influence in maintaining price stability within the Nigeria economy. The study concluded that for monetary policy to achieve its other macroeconomic objective such as economy growth there is the need to reduce the excessive expenditure of the government and align fiscal policy along with monetary policy measure. 


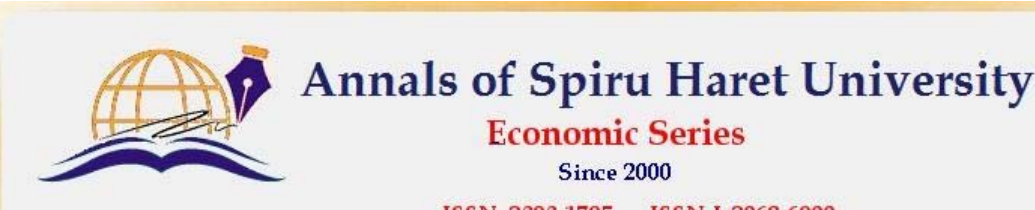

ISSN: 2393-1795 ISSN-L:2068-6900

\section{Issue 1/2018}

Fasanya, Onakoya and Agboluaje (2013) have examined the impact of monetary policy on economic growth in Nigeria. The study used time-series data covering the range of 1975 to 2010 . The effects of stochastic shocks of each of the endogenous variables are explored using Error Correction Model (ECM). The study showed that long-run relationship exists among the variables. In addition, the core finding of this study showed that inflation rate, exchange rate and external reserve are significant monetary policy instruments that drive growth in Nigeria.

Chimobi and Uche (2010) examined the relationship between Money, Inflation and Output in Nigeria. The study adopted co-integration and granger-causality test analysis. The co-integrating result of the study showed that the variables used in the model exhibited no long run relationship among each other. Nevertheless, money supply was seen to granger cause both output and inflation. The result of the study suggested that monetary stability can contribute towards price stability in the Nigerian economy since the variation in price level is mainly caused by money supply and concluded that inflation in Nigeria is to an extent a monetary phenomenon.

Onyeiwu (2012) examines the impact of monetary policy on the Nigerian economy using the Ordinary Least Squares Method (OLS) to analyse data between 1981 and 2008. The result of the analysis shows that monetary policy presented by money supply exerts a positive impact on GDP growth and Balance of Payment, but negative impact on rate of inflation. Furthermore, the findings of the study support the money-prices-output hypothesis for Nigerian economy. Obviously, the empirical studies on monetary policy and real output growth in Nigeria is still scanty.

\section{Methodology}

The study is an ex-post facto research. The variables for the study are based on secondary data sources. The data are sourced from the CBN Statistical bulletin, 2017 edition. The time series covers the market based economic era when monetary policies are seen to be the main stand-post of economies across the world. Thus, the data covers 1986 to 2016 . This study employs annual data on the monetary policy rate, rate of inflation, money supply, exchange rate, interest rate as the explanatory variables and the Gross Domestic Product as the proxy foe, economic growth as the dependent variable.

The Keynesian IS-LM function serves as a platform on which the empirical model is formulated as follows. Following McCallum (1991), the following equation is then derived. The present study followed this theoretical function in line with Fasanya, Onakoya and Agboluaje (2013) that employed real Gross Domestic Product; money supply; interest rate; inflation rate; exchange rate; external reserve 130 

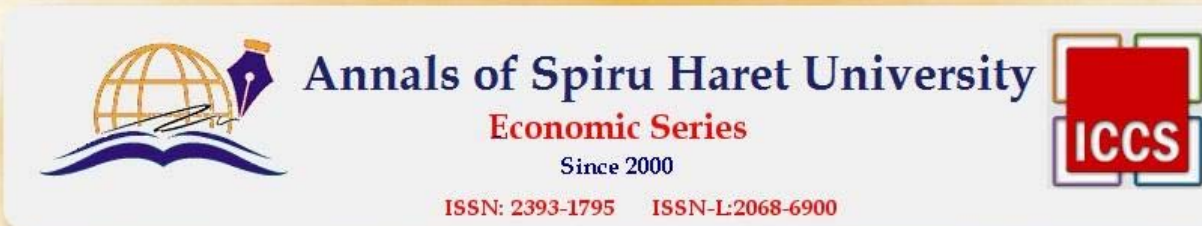

ISSN: 2393-1795 ISSN-L:2068-6900

Issue 1/2018

in their study. The model also follows Adegbite and Alabi (2013), whom have regressed output of industrial production, inflation, money supply, exchange rate, and interest rate against economic growth proxied by GDP. The present study modified both models to include monetary policy rate in order to capture the core main tool of monetary policy that influences all other monetary policy targets. The study also replaced external reserves and output of industrial production with investment because investment is theoretically postulated to have direct influence from interest rates (lending and deposit rates), which the CBN monetary policy rates directly influence. The model of this study is thus:

$\mathrm{GDP}=\mathrm{f}(\mathrm{MPR}, \mathrm{MS}, \mathrm{EXCH}, \mathrm{INT}, \mathrm{INV})$

Where:

GDP $=$ Gross Domestic Product at current market prices

MPR $=$ Monetary policy rate

MS = Money supply proxied by the broad money supply (M2)

$\mathrm{EXCH}=$ Real exchange rate

INT $=$ Interest rate proxied by bank lending rate.

$\mathrm{INV}=$ Investment to the productive sector proxied by Credit to the private sector.

The equation of the model is thus:

$$
\mathrm{LnGDP}=\beta_{0} \beta_{1} \mathrm{MPR}+\beta_{2} \mathrm{LnMS}+\beta_{3} \mathrm{EXCH}+\beta_{4} \mathrm{INT}+\beta_{5} \mathrm{LnINV}+\mu
$$

$\mathrm{Ln}=$ Natural Logarithm of the variables used to smoothen possible scholastic effect from variables at level. $\beta_{0}$ is the constant while $\beta_{1}-\beta_{5}$ are the coefficients of the relationships between the independent variables and the dependent variable. $\mu$ is the stochastic error term for the time period covered by the study.

$$
\beta_{1}<\mathrm{O}, \beta_{2}>0, \beta_{3}<0, \beta_{4}<0, \beta_{5}>0 \text {. }
$$

The study follows the arguments set out in the standard Mundell-FlemingDornbush model, which assumes a priori, that expansionary monetary policy reduces interest rates, depreciates the real exchange rate and increases prices (i.e. 


\section{Issue 1/2018}

inflation), money supply and the level of real output [Rafiq and Mallick, 2008]. Based on the expansionary assumption, the expected $a$ priori is that:

- $\mathrm{B}_{0}$ is to take care of the constant variable;

- $\beta_{1}$ is the coefficient of monetary policy rate (MPR), which is expected to be less than zero $\left(\beta_{2}<0\right)$ due to its negative relationship with the gross domestic product in Nigeria;

- $\beta_{2}$ is the coefficient of money supply (MS), which is expected to be greater than zero $(\beta 2>0)$, because it is positively related to gross domestic product in Nigeria;

- $\beta_{3}$ is the coefficient of exchange rate $(\mathrm{EXCH})$, which is expected to be greater than zero $(\beta 2>0)$ due to its positive relationship with gross domestic product in Nigeria;

- $\beta_{4}$ is the coefficient of interest rate (INT), which is expected to be less than zero $(\beta 2<0)$ due to its negative relationship with the gross domestic product in Nigeria;

- $\mathrm{B}_{5}$ is the coefficient of investment (INV) which is expected to be greater than zero $(\beta 5>0)$, because it is positively related to gross domestic product in Nigeria.

Econometric regression estimation were performed to investigate the effect of monetary policy on economic growth. As most economic time series variables are found to exhibit nonstationary and lead to spurious or fake regression [Gujarati \& Porter, 2009], the study employs the Augmented Dicker Test [Dickey \& Fuller, 1979] to determine the stationary of the variables used. Then, the study adopts Johansen (1991) co-integration test to determine the long-run relationship, between the dependent and independent variables. The direction and significance of the effect of monetary policy on economic growth is then examined with the Ordinary least squares (OLS) regression model. The coefficient of determination $\left(\mathrm{R}^{2}\right)$, F-test, t-test, beta and Durbin-Watson were used in the interpretation of the results. Student T-Test measures the individual significance of the estimated independent variables. F-Test measures the overall significance. The coefficient is used to measure the individual contribution of the variables to variation in the dependent variable. Durbin Watson (DW) Statistics tests for auto correlation in the regression.

The Granger Causality test was also performed to determine the casual between monetary policy variables and economic growth (GDP). 
Issue 1/2018

\section{Analyses and interpretation of results}

Table no. 1. ADF Unit Root test for Stationarity (with constant, no trend)

\begin{tabular}{|c|c|c|c|c|c|}
\hline \multicolumn{2}{|c|}{ Variables } & $\begin{array}{c}\text { At Level } \\
\mathbf{1 ( 0 )} \\
\end{array}$ & $\begin{array}{c}\text { First Difference } \\
\mathbf{1 ( 1 )} \\
\end{array}$ & $\begin{array}{c}\text { Order of } \\
\text { Integration }\end{array}$ & Remark \\
\hline \multicolumn{2}{|l|}{ LnGDP } & -1.311578 & $-4.115498^{*}$ & $1(1)$ & Stationary \\
\hline \multicolumn{2}{|l|}{ MPR } & -2.157415 & $-5.426151 *$ & $1(1)$ & Stationary \\
\hline \multicolumn{2}{|l|}{ LnMS } & -1.626638 & -2.389475 & & Non Stationary \\
\hline \multicolumn{2}{|l|}{$\mathrm{EXCH}$} & -0.566438 & $-3.325049 * *$ & $1(1)$ & Stationary \\
\hline \multicolumn{2}{|l|}{ INT } & $-2.664755^{* * *}$ & $-5.148422 *$ & $1(1)$ & Stationary \\
\hline \multicolumn{2}{|l|}{ LnINV } & -0.349929 & $-3.740636^{*}$ & $1(1)$ & Stationary \\
\hline \multirow{3}{*}{$\begin{array}{l}\text { Critical } \\
\text { values }\end{array}$} & $1 \%$ & -3.7076 & -3.7204 & & \\
\hline & $5 \%$ & -2.9798 & -2.9850 & & \\
\hline & $10 \%$ & -2.6290 & -2.6318 & & \\
\hline
\end{tabular}

Notes:

1) Null hypothesis is the presence of unit root.

2 ) $* 1 \%$ level of significance, $* * 5 \%$ level of significance, $* * * 10 \%$ level of significance.

3) Unit roots tested at 5\% level of significance.

4) Decision rule - The critical value should be larger than the test statistical value for unit root to exist

Source: Researcher's Estimation using Eviews.

The unit root/stationary test is shown on Table 1. Unit root analysis is a test conducted to ascertain if the variables under consideration are stationary. We take the following decision rule: if the absolute value of the Augment Dickey Fuller (ADF) test is greater than the critical value either at $1 \%, 5 \%$ or $10 \%$ level of significance at the order of zero, one, or two, it shows that variables under consideration are stationary, otherwise they are not. The results of the unit root test show that none of the critical values of the variables are greater than the ADF statistical values at level. However, LnGDP, MPR, EXCH, INT and INV are stationary at first difference [1(1)]. Only the LnMS is stationary at second difference [1(2)]. Since most of the variables are integrated at the same order, that 


\section{Issue 1/2018}

is, at first order, we therefore suspect evidence of co-integration in the model, the result is presented below.

Table no. 2. Co-integration Test for Long-run Relationship between Monetary Policy and GDP

Sample: 19862016

Included observations: 29

Test assumption: Linear deterministic trend in the data

Series: LnGDP MPR LnMS EXCH INT LnINV

Lags interval: 1 to 1

\begin{tabular}{ccccc}
\hline \hline Eigenvalue & $\begin{array}{c}\text { Likelihood } \\
\text { Ratio }\end{array}$ & $\begin{array}{c}\text { 5 Percent } \\
\text { Critical Value }\end{array}$ & $\begin{array}{c}\text { 1 Percent } \\
\text { Critical Value }\end{array}$ & $\begin{array}{c}\text { Hypothesized } \\
\text { No. of CE(s) }\end{array}$ \\
\hline \hline 0.861805 & 126.0999 & 94.15 & 103.18 & None ** \\
0.686450 & 74.64356 & 68.52 & 76.07 & At most 1 * \\
0.579114 & 44.48888 & 47.21 & 54.46 & At most 2 \\
0.332831 & 21.98864 & 29.68 & 35.65 & At most 3 \\
0.257224 & 11.46612 & 15.41 & 20.04 & At most 4 \\
0.133804 & 3.734749 & 3.76 & 6.65 & At most 5 \\
\hline \hline
\end{tabular}

$*(* *)$ denotes rejection of the hypothesis at $5 \%(1 \%)$ significance level

L.R. test indicates 2 co-integrating equation(s) at 5\% significance level Source: Researcher's Estimation using Eviews.

The results of the multivariate co-integration tests were validated using the Johansen $(1991,1995)$ approach. The Johansen's framework provides a number of co-integrating equations and estimates of all co-integrating vectors in the multivariate case. The Johansen co-integration test result is presented in Tables 4.2. The likelihood ratios were conducted to establish the number of co-integrating relations in each of the equations. Test results indicate the existence of two cointegrating equations in the equations at the $1 \%$ and $5 \%$ significance level. Thus, we conclude that there is long-run relationship between monetary policy and economic growth in Nigeria. 
Issue $1 / 2018$

Table no. 3. Test of the Direction and Significance of the Relationship between Monetary Policy and GDP

Dependent Variable: LnGDP

Sample: 19862016

Included observations: 31

\begin{tabular}{crrrr}
\hline \hline Variable & Coefficient & Std. Error & t-Statistic & Prob. \\
\hline MPR & 0.017958 & 0.015539 & 1.155698 & 0.2602 \\
LnMS & 1.305625 & 0.383575 & 3.403832 & 0.0025 \\
EXCH & -0.005700 & 0.002409 & -2.366476 & 0.0272 \\
INT & 0.002401 & 0.015245 & 0.157502 & 0.8763 \\
LnINV & 0.223778 & 0.346292 & 0.646212 & 0.5248 \\
C & 1.341845 & 0.485953 & 2.761267 & 0.0114 \\
\hline R-squared & 0.985763 & & & \\
Adjusted R-squared & 0.982527 & & & \\
F-statistic & 304.6520 & & & \\
Prob(F-statistic) & 0.000000 & & & \\
Durbin-Watson stat & 0.924534 & & & \\
= & $=$
\end{tabular}

Source: Researcher's Estimation using Eviews.

From Table 3 above, the adjusted coefficient of determination (Adj $\mathrm{R}^{2}$ ) shows that about $98 \%$ of the changes in economic growth can be explained by monetary policy. This implies that monetary policy can be effectively used to control Nigerian economy. Additionally, the F-statistics (304.6520) has probability less than 5\%, which indicate that monetary policy variables included in the model has combined significant effect on economic growth in Nigeria. This supports the result of the Adj $\mathrm{R}^{2}$ and further confirms that monetary policy is a veritable tool for price stability and improved output.

However, the contributions and significance of the individual coefficients of the model is used to test for hypotheses for this study using the t-test. Each of the hypotheses is tested with the coefficient and the t-values.

$\mathrm{HO}_{1}$ : Monetary policy rate has no significant effect on GDP in Nigeria

The coefficient of the MPR is 0.017958 , which means that monetary policy rate has positive relationship with GDP. This indicates that a unit increase in MPR 


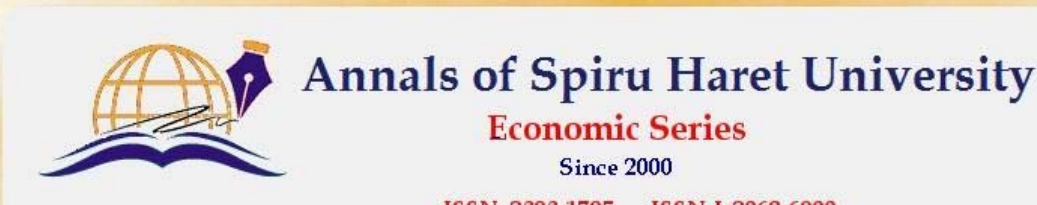

ISSN: 2393-1795 ISSN-L:2068-6900

\section{Issue 1/2018}

will lead to $1.7 \%$ increase in GDP. The t value is 1.155698 with probability value of 0.2602 . Since the $p$ value is not less than $5 \%$, we do not reject the null hypothesis and conclude that monetary policy rate has no significant effect on GDP in Nigeria.

$\mathrm{HO}_{2}$ : Money supply has no significant effect on GDP in Nigeria.

The coefficient of the LnMS is 1.305625 , which means that broad money supply has positive relationship with GDP. This indicates that a unit increase in LnMS will lead to $130 \%$ increase in GDP. The $t$ value is 3.403832 with probability value of 0.0025 . Since the $\mathrm{p}$ value is less than $5 \%$, we reject the null hypothesis and conclude that money supply has significant effect on GDP in Nigeria.

$\mathrm{HO}_{3}$ : Exchange rate has no significant effect on GDP in Nigeria.

The coefficient of the LnMS is -0.005700 , which means that the exchange rate has negative relationship with GDP. This indicates that a unit increase in EXCH will lead to $0.57 \%$ fall in GDP. The $t$ value is -2.366476 with probability value of 0.0272 . Since the p value is less than $5 \%$, we reject the null hypothesis and conclude that exchange rate has significant effect on GDP in Nigeria.

$\mathrm{HO}_{4}$ : Interest rate has no significant effect on GDP in Nigeria.

The coefficient of the MPR is 0.002401 , which means that the interest rate has positive relationship with GDP. This indicates that a unit increase in MPR will lead to $0.2 \%$ increase in GDP. The $t$ value is 0.157502 with probability value of 0.8763 . Since the $\mathrm{p}$ value is not less than $5 \%$, we do not reject the null hypothesis and conclude that interest rate has no significant effect on GDP in Nigeria.

$\mathrm{H}_{5}$ : Investment growth has no significant effect on GDP in Nigeria.

The coefficient of the MPR is 0.223778 , which means that there investment has positive relationship with GDP. This indicates that a unit increase in MPR will lead to $22 \%$ increase in GDP. The $\mathrm{t}$ value is 0.646212 with probability value of 0.5248 . Since the $\mathrm{p}$ value is not less than $5 \%$, we do not reject the null hypothesis and conclude that investment has no significant effect on GDP in Nigeria.

At 5\% level of significance, we found the following causal relations: in Nigeria.

1 . There is no causality between monetary policy rate and economic growth

2. Money supply causes economic growth in Nigeria.

3 . There is no causality between exchange rate and economic growth in Nigeria. 
Issue 1/2018

4. Economic growth (GDP) causes interest rate in Nigeria.

5. Investment causes economic growth in Nigeria.

Table no. 4. Pairwise Granger Causality Tests

\begin{tabular}{|c|c|c|c|c|}
\hline Null Hypothesis: & Obs & F-Statistic & Probability & Interpretation \\
\hline $\begin{array}{l}\text { MPR does not Granger Cause } \\
\text { GDP }\end{array}$ & 27 & 2.15534 & 0.14080 & No causality \\
\hline GDP does not Granger Cause MPR & & 2.31754 & 0.12318 & \\
\hline $\begin{array}{l}\text { MS does not Granger Cause GDP } \\
\text { GDP does not Granger Cause MS }\end{array}$ & 27 & $\begin{array}{c}4.57481^{*} \\
0.30730\end{array}$ & $\begin{array}{l}0.02243 \\
0.73868\end{array}$ & $\begin{array}{c}\text { Uni-directional } \\
\text { causality (MS --> GDP) }\end{array}$ \\
\hline $\begin{array}{l}\text { EXCH does not Granger Cause } \\
\text { GDP } \\
\text { GDP does not Granger Cause EXCH }\end{array}$ & 27 & 1.75029 & 0.19813 & No causality \\
\hline $\begin{array}{l}\text { INT does not Granger Cause GDP } \\
\text { GDP does not Granger Cause INT }\end{array}$ & 2 & $\begin{array}{c}0.45850 \\
5.20179^{*}\end{array}$ & $\begin{array}{l}0.63841 \\
0.01462\end{array}$ & $\begin{array}{l}\text { Uni-directional } \\
\text { causality (GDP --> } \\
\text { INT) }\end{array}$ \\
\hline $\begin{array}{l}\text { INV does not Granger Cause GDP } \\
\text { GDP does not Granger Cause INV }\end{array}$ & 27 & $\begin{array}{c}5.37514^{*} \\
1.11691\end{array}$ & $\begin{array}{l}0.01303 \\
0.34597\end{array}$ & $\begin{array}{c}\text { Uni-directional } \\
\text { causality (INV --> } \\
\text { GDP) }\end{array}$ \\
\hline
\end{tabular}

Source: Researcher's Estimation using Eviews.

\section{Conclusions}

The study has investigated the effect of monetary policy on economic growth. Monetary policy is found to have long-run relationship with the economic growth and can be effectively used to control Nigerian economy and thus is a veritable tool for price stability and improve output. In addition, the core finding of this study showed that monetary policy rate, interest rate, and investment have insignificant positive effect on economic growth in Nigeria. Money supply however has significant positive effect on growth in Nigeria. Exchange rate has significant negative effect on GDP in Nigeria. Money supply and investment causes economic growth, while economic growth causes interest rate in Nigeria. On the overall, monetary policy explains $98 \%$ of the changes in economic growth in Nigeria. However, it is shown that money supply and investment cause economic growth and economic growth causes interest rate in Nigeria. 


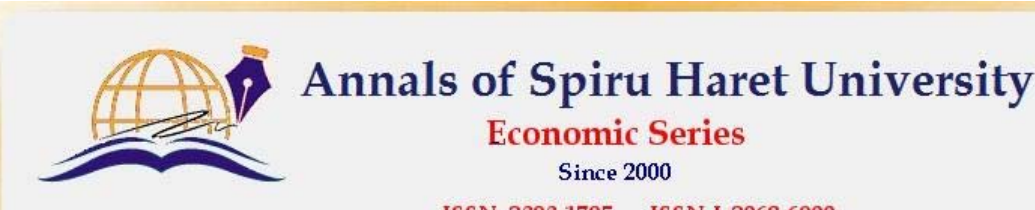

ISSN: 2393-1795 ISSN-L:2068-6900

Issue 1/2018

\section{Recommendations}

Based on the findings made in the course of this study, the following recommendations are hereby suggested below:

1 . The connection between monetary expansions and real economic growth capitalizes on imperfections in the public's information about prices. People respond inefficiently in the sense that under perfect information, they would not have altered their behaviour. At best, one party gains at another's expense. A central bank may periodically exploit this connection, but frequent attempts, as some seem to advocate, may ultimately distort the allocation of resources from productive uses to protective enterprises. Countries with high inflation rates tend to have larger financial sectors relative to GDP, not faster rates of economic growth In the long-run, money growth seems to translate only into proportionally higher inflation; it does not foster real economic growth or employment. Ultimately, a central bank can best contribute to a nation's economic health by eliminating the price uncertainties associated with inflation. However, if the central bank restrains from interventions, sharp fluctuations may result in the market.

2. Monetary policies should be used to create a favourable investment climate by facilitating the emergency of market based interest rate and exchange rate regimes that attract both domestic and foreign investments, create jobs, promote non-oil export and revive industries that are currently operation far below installed capacity. In order to strengthen the financial sector, the Central Bank has to encourage the introduction of more financial instruments that are flexible enough to meet the risk preferences and sophistication of operators in the financial sector.

3. For monetary policy to have a desired impact on the real economy and inflation, which is the fundamental objective of monetary policy, it is essential that changes in the short-term market interest rate should ultimately transform into changes in other interest rates in the economy (that is, interest rate changes are passed through to retail interest rates for loans and deposits), which then influence the overall level of economic activity and prices.

4. It is therefore prudent that in seeking to promote economic growth, Nigeria's banks should be committed to the mission of price stability, as well as improving the regulatory and supervisory frameworks to secure a strong financial sector for efficient intermediation.

\section{References}

Adefeso, H. A. \& Mobolaji, H. I., "The fiscal-monetary policy and economic growth in Nigeria: Further empirical evidence," Pakistan Journal of Social Sciences, 7(2), (2010): 137-142. Retrieved from 10.3923/pjssci.2010.137.142. 


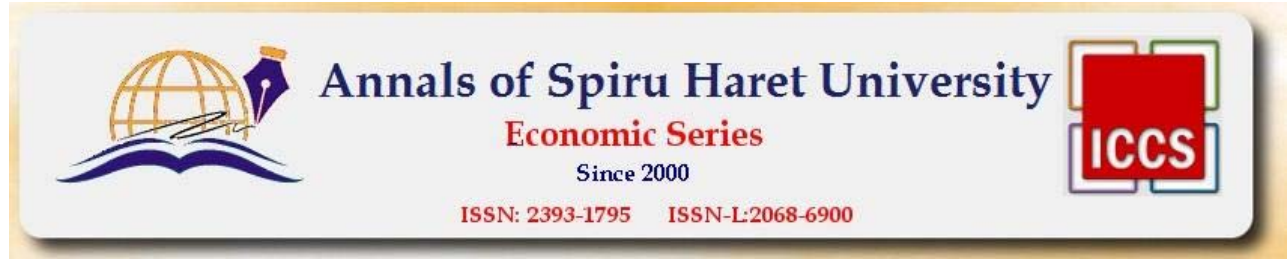

Issue 1/2018

Adegbite, T. A. \& Alabi, W. O., "Monetary policy and economic growth: The Nigerian experience (1970-2010)," Prime Journal of Business Administration and Management, 3(1), (2013): 822-833. Retrieved from www.primejournal.org/BAM/pdf/.../Adejare\% 20and\%20Omodara.doc.p.

Amassoma, D., Nwosa, P. I. \& Olaiya, S. A., “An appraisal of monetary policy and its effect on macroeconomic stabilization in Nigeria," Journal of Emerging Trends in Economics and Management Sciences, 2(3), (2011): 232-237. Retrieved from www.jetems.scholarlinkresearch.org.

CBN, "What is Monetary Policy?" Understanding Monetary Series No. 1 (2011).

Chimobi, O. P. \& Uche, U. C., "Money, price and output: A causality test for Nigeria," American Journal of Scientific Research, 8, (2010): 78-87.

Chuku, A. C., "Measuring the effects of monetary policy innovations in Nigeria," Africa Journal of Accounting, Economics, Finance and Banking Research, 5(5), (2009): 112-129. Retrieved from http://www.researchgate.net/publication/228272597 Measuring_the_Effects_of_Monetary_Policy_Innovations_in_Nigeria_A_Structural_ Vector_Autoregressive_\% $\% \overline{28 S V A R} \% \overline{29}$ _Approach/file/3deec $\overline{5} 1 \mathrm{a} 939 \mathrm{e} \overline{5} 6 \mathrm{eeb} 7 . \mathrm{pdf}$

Danjuma, I., Jbrin, S. M. \& Blessing, S. E., "An assessment of the effectiveness of monetary policy in combating inflation pressure on the Nigerian economy," Erudite Journal of Business Administration and Management, 1(1), (2012): 7-16. Retrieved from www.eruditejournals.org/ejbam.

Diamond, R., "Irving Fisher on the international transmission of boom and depression through money standard," Journal of Money, Credit and Banking, 35, (2003): 49-58.

Dickey, D. \& Fuller W., "Distribution of the Estimators for Autoregressive Time Series with a Unit Root," Journal of American Statistical Association, 74, (1979): 427-431.

Dwivedi, D. N., Managerial Economics (Sixth Edition. VIKAS Publishing house PVT LTD, New Delhi India, 2005).

Fasanya, I. O., Onakoya, A. B. O. \& Agboluaje, M. A., "Does Monetary Policy Influence Economic Growth In Nigeria?" Asian Economic and Financial Review, 3(5), (2013): 635-646. Retrieved from www.aessweb.com/download.php?id=1883.

Friedman, M., "The role of monetary policy," American Economic Review, 58(1), (1968): $1-17$.

Gujarati, N. D., Basic Econometrics. 4th Edition (Tata: McGraw-Hill Publishing, 2009).

Gul, H., Mughal, K. \& Rahim, S., "Linkage between monetary instruments and economic growth," Universal Journal of Management and Social Sciences, 2(5), (2012): 69-76.

Hardwick, P., Khan, B. \& Langmead, J., An Introduction to Modern Economics, (4th ed.) (England: Longman Group Ltd, 1994).

Jinghan, M.L., Acroeconomic Theory, 10th Revised \& Enlarged Edition (Vrinda Publications (P) Ltd, 2004), p. 99.

Johansen, S., "Cointegration and Hypothesis Testing of Cointegration Vectors in Gaussian Vector Autoregressive Models,” Econometrica, 59(6). (1991): 1551-1580. 


\section{Annals of Spiru Haret University \\ Economic Series \\ Since 2000}

ISSN: 2393-1795 ISSN-L:2068-6900

\section{Issue 1/2018}

Keynes, J., Treatise on money (London: Macmillian, 1930).

Ogbulu, O. M. \& Torbira, L. L., "Budgetary Operations and Economic Growth: The Nigerian Perspective," British Journal of Arts and Social Sciences, 4(2), (2012): 180-194. Retrieved from http://www.bjournal.co.uk/BJASS.aspx.

Ogunjimi, S. O., Public Finance: For Polytechnics ICAN Students (Bida: Lekem Productions, 1997).

Okafor, P. N., "Monetary Policy Framework in Nigeria: Issues and Challenges," CBN Economic and Financial Review, 33(2), (2009).

Onyeiwu, C., "Monetary policy and economic growth of Nigeria," Journal of Economics and Sustainable Development, 3(7), (2012): 62-70. Retrieved from www.iiste.org/ Journals/index.php/JEDS/article/viewFile/2046/2025.

Russell, M., "Monetary policy and interest rates," Ezine articles, What is the monetary policy effect on GDP. Unemployment, inflation and interest rates. (2010).

Uchendu, O. A., "Monetary Policy in Nigeria," CBN Economic and Financial Review 33(2), (2009): 11-18. 